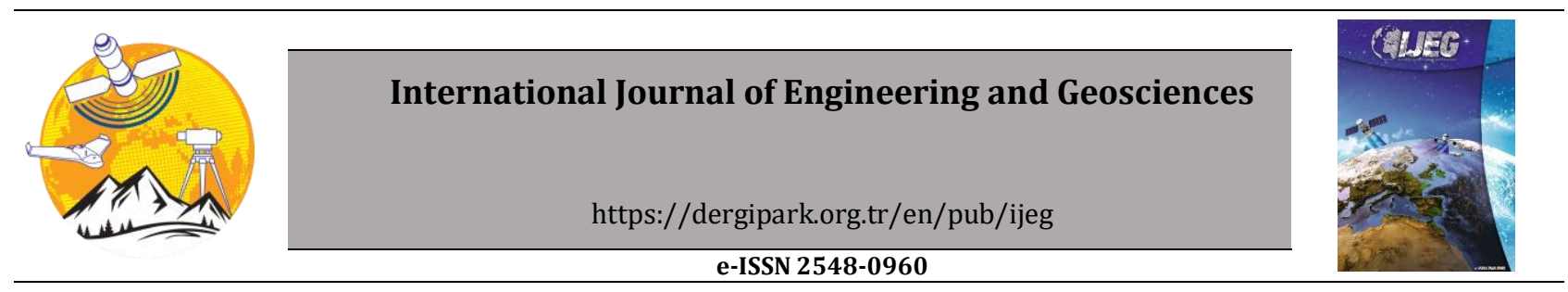

\title{
Multi criteria decision analysis to determine the suitability of agricultural crops for land consolidation areas
}

\author{
Fatih Sarı $^{* 1}$, Fatma Koyuncu Sarı 2 (อ) \\ ${ }_{1}^{1}$ Selcuk University, Cumra Applied Sciences, Department of Geomatics Information Systems, Konya, Turkey \\ ${ }^{2}$ Selcuk University, Faculty of Agriculture, Department of Landscape Architecture, Konya, Turkey
}

\author{
Keywords \\ Multi-Criteria decision analysis \\ Analytical hierarchy process \\ TOPSIS \\ Geographical information \\ systems \\ Sustainable land management
}

\begin{abstract}
Crop selection for sustainable and effective agricultural land management has to take into accounts several issues such as chemical, physical, environmental, economic and social conditions. Especially after land consolidation projects, sustainable agricultural crop management should be investigated for each crop which are suitable for the project area to benefit from the land consolidation contributions such as irrigation, roads, modified parcel boundaries and surfaces. Thus, Geographical Information Systems (GIS) aided suitability analysis techniques are required to determine the suitable crops for the consolidated areas. In this study, Analytic Hierarchy Process (AHP) and Technique for Order Preference by Similarity to Ideal Solution (TOPSIS) multi-criteria decision techniques are integrated with GIS to determine most suitable crops for parcels. The suitability maps of wheat, clover, sugar beet and corn crops are generated for the projected area using 63 Land Mapping Units (LMU) with considering $\mathrm{pH}$, lime, texture, salinity, organic matter, electrical conductivity, permeability, slope, aspect and the distance to settlements and roads within chemical, physical, topological and socio-economic criteria.
\end{abstract}

\section{INTRODUCTION}

The agricultural activities have an importance that can accelerate the development of a country with its economic proceeds. There is a very close relation between the agricultural lands of a city and its economic-social status. Thus, the planning of agricultural activities and establishing Sustainable Agriculture Management (SAM) systems in developing cities are very important in the field of economic, social and environmental criteria (Rigby et al. 2001; Cauwenbergh et al. 2007; Radulescu et al. 2011; Akar and Gökalp 2018).

Crop suitability analysis, sustainable agricultural yield, pest control and irrigation are involved in SAM environment. Especially in land consolidation projects, site suitability analysis for crop selection is getting more essential to benefit from the advantages of land consolidation projects.
The Food and Agricultural Organisation (FAO) suggested an approach for crop suitability via a ranking from suitable to not suitable including soil properties, climatic conditions and land facilities (FAO 1976). Addition to this, crop suitability requires considering chemistry and physics of soil, topographic, climatic and environmental data when deciding (Wang et al. 1990; Joerin et al. 2001; Ceballos-Silva and Lopez-Blanco 2003a; Eliasson et al. 2010; Yu et al. 2011; Confalonieri et al. 2013; Elsheikh et al. 2013).

The existence of a wide range data in crop suitability and the complexity of criteria are the scope of Multi Criteria Decision Analysis (MCDA) (Zolekar and Bhagat 2015). MCDA is a general term that refers to determine the best alternative from all of the existing alternatives in the presence of multiple criteria (Zeleny 1982; Radulescu et al. 2010; Ramírez-García et al. 2015). 
In this concept, Analytical Hierarchy Process (AHP) is one of the most applied methods in MCDA, which aims to calculate weights for each criterion among the parameters that involved in crop suitability (Saaty 1977, Saaty 1994, Saaty 2001; Saaty and Vargas 1991). AHP involves the calculations to determine most suitable solutions to the desired problem within multiple criteria by calculating weights with a pairwise comparison matrix (Arentze and Timmermans 2000; Chen et al. 2010). Calculated weights represent the affect rate of each criterion to the total suitability. On the other hand, TOPSIS is another method based on determining the distances, which has the shortest distance to positive ideal solution and longest distance from negative ideal solution (Hwang and Yoon 1981; Sarı et al. 2020).

In literature, there are considerable amounts of researches, which initialize the suitability of crops. The common alternative cropping systems via MCDA, cover crop species and cultivars selection were studied by (Hayashi 2000; Prakash 2003; Sadok et al. 2008; Thapa and Murayama 2008; Chen et al. 2010; Ramírez-García et al. 2015). The other studies were based on a special crop such as; strawberry and rubber tree (Roudeillac et al. 1997; Diaby et al. 2010), walnut cultivars (Srdjevic et al. 2004); lilium species and clones (Li et al. 2011); maize and potato (Ceballos-Silva and Lopez-Blanco, 2003b); tobacco (Chavez et al. 2012); faba bean (Kazemi et al. 2016); oat crop (Ceballos-Silva and Lopez-Blanco 2003a); olive crop (Elaalem 2013), the fruit crops (Chuong 2007), biomass crop (Cobuloglu and Buyuktahtakın 2015), paddy crops, vegetable and flower, annual crops, mulberry, coffee and tea (Dinh and Duc 2012). Although one crop type is examined in recent studies, most common agricultural crop types were studied in this paper and addition to AHP, TOPSIS method was used for crop suitability. The study area and parcel counts are one of the largest of recent studies and land consolidation area was used in this study.

In this study, AHP and TOPSIS methods are integrated to determine the suitability of corn, clover, wheat and sugar beet, which are the main crops of the study area, for consolidated lands in Seydişehir, Konya. There are 63 Land Map Units (LMU) units and their chemical, physical, topographical and socio-economic features are considered which are obtained from soil survey analysis of the project area. LMU's are the soil survey points, which are established before land consolidation projects to define the soil properties by taking soil samples. The suitability maps for crops are generated with MCDA and Geographical Information Systems (GIS) integration. The results of the study can guide to the crop management and irrigation planning by determining suitable parcels for crops to increase the sustainable agricultural activities and economic income. The results can also guide to land consolidation projects considering the crop cover.

\section{MATERIALS and METHODS}

\subsection{Study Area}

The study area Seydişehir-Gevrekli is a land consolidation project area located in Konya city and the city has 18763439 ha agricultural lands according to the 2019 statistics (URL 1). This mean, Konya has the largest agricultural lands in Turkey. The topography of the study area and the parcels used in this study are shown (Figure 1).

Seydişehir is a district of Konya and surrounded with Çumra, Bozkır, Akseki and Beyşehir districts. The district has an average height of 1123 meter above sea level and about $2000 \mathrm{~km}^{2}$ of agricultural lands. The topography of Seydişehir is mostly a plain in the middle of the city and have high mountains (The Taurus Mountains) in the south of the city that compose the boundary with the Mediterranean region and its climate.

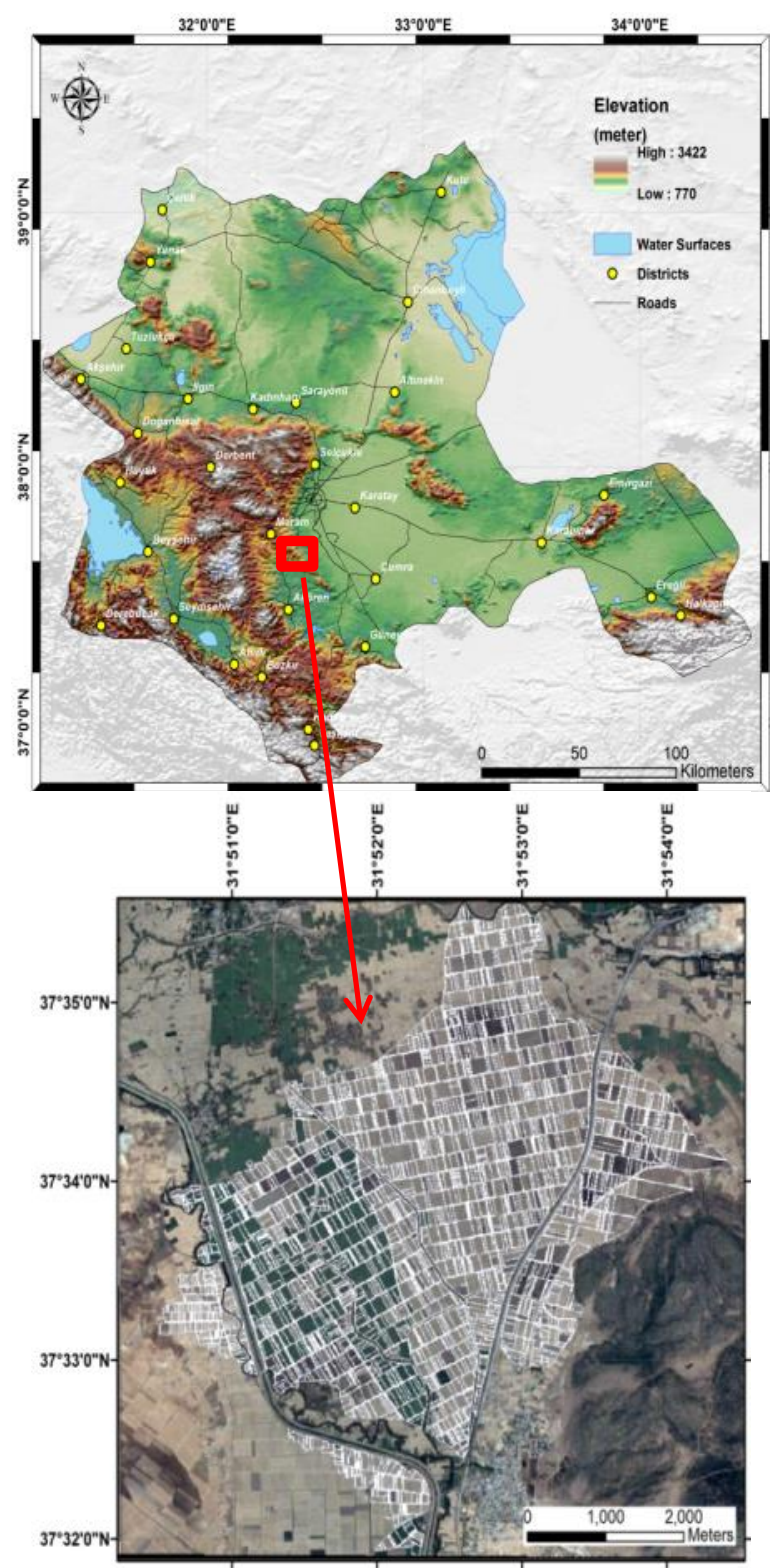

Figure 1. The study area Gevrekli 
The $\mathrm{pH}$ of the soil is varied from slightly acid to strongly alkaline that suitable for a large amount of agricultural crops. The salinity values are appropriate for most of the crops and there are quite a few areas, which have slightly, and moderately salinity. The lime rate of the soils can rise to $46 \%$.

The common texture of the area is loamy and clay-loamy which can be accepted as appropriate for most of the agricultural crops. The common area has poor organic matter rate; thus, fertilizer usage should be considered for agricultural crops. The area has an average $2 \%$ slope commonly except the east of the study area.

\subsection{Methodology}

The application model consists of a combination of AHP and TOPSIS. GIS functions will contribute the visualization and generating suitability maps.

\subsubsection{Criteria selection}

When deciding criteria, which will be included in suitability analysis, the requirements of the crops must be specified in the field of chemical, physical, topographic and socio-economic perspective according to the expert decisions and recent studies. The chemical criteria are specified considering soil survey analyses, which are examined for land consolidation projects. Soil pH, lime, organic matter, salinity, electrical conductivity and boron parameters are included in chemical criteria and expected to be in required interval for crops. The physical criteria include texture and permeability, which are related to the soil nature. The topographical criteria include slope and aspect related to the drainage, irrigation and temperature. Finally, the socio-economic criterion includes distances from settlements and roads to consider crop storage and transportation.

All the requirements are determined and arranged as a table, which is given in Table 1 for corn crop. The classifications of the soil requirements are obtained from the fertilizer producers. In crop suitability analysis, all values are converted to a rating system with ordinal values (like S1, S2, S3, N1 and $\mathrm{N} 2$ ) representing the degree of suitability of LMU based on the crop requirements (URL 2). S1, S2 and S3 are indicating the marginally suitable areas and N1, N2 extremely unsuitable areas for selected crop.

Table 1. Corn requirements

\begin{tabular}{llllll}
\hline Corn & S1 & S2 & S3 & N1 & N2 \\
\hline pH (Class) & $6-6,5$ & $6,5-7$ & $5,5-6$ & $5-5,5$ & $<5,0$ \\
Boron (ppm) & 0,1 & 0,2 & 0,3 & 0,8 & $>1$ \\
Lime (\%) & $<1$ & $1-3$ & $3-5$ & $5-25$ & $>25$ \\
OM (\%) & $>10$ & $10-5$ & $5-2$ & $2-1$ & $1>$ \\
Salt (mmhos/cm) & $2-3,5$ & $3,5-5$ & $2-1$ & $5-10$ & $>10$ \\
EC (mmhos/cm) & $0-1$ & $1-2$ & $2-3$ & $3-5$ & $>5$ \\
Texture (Class) & CL & L & C & S & - \\
Permeability (Class) & $>4$ & $4-3$ & $3-2$ & $2-1$ & $>1$ \\
Slope (\%) & $>1$ & $1-2$ & $2-5$ & $5-10$ & $>10$ \\
Aspect (Class) & South & East & West & North & - \\
\hline
\end{tabular}

\subsubsection{Analytic hierarchy process (AHP)}

The procedure outlined by (Saaty 1977) scales the importance of each criterion, from 1 to 9 relatively (1=Equal, 3=Moderately, 5=Strongly, $7=$ =ery, 9=Extremely). The reciprocal values 2, 4, 6 and 8 also refer to importance values within 1 to 9 importance scale of Saaty. The pairwise matrix (Eq.1) includes the scales and determines the importance of criteria.

\begin{tabular}{llllll}
\hline A & C 1 & C 2 & C 3 & $\ldots$ & C n \\
\hline C 1 & $\mathrm{a}_{11}$ & $\mathrm{a}_{12}$ & $\mathrm{a}_{13}$ & $\ldots$ & $\mathrm{a}_{1 \mathrm{n}}$ \\
C 2 & $\mathrm{a}_{21}$ & $\mathrm{a}_{22}$ & $\mathrm{a}_{23}$ & $\ldots$ & $\mathrm{a}_{2 \mathrm{n}}$ \\
C 3 & $\mathrm{a}_{31}$ & $\mathrm{a}_{32}$ & $\mathrm{a}_{33}$ & $\ldots$ & $\mathrm{a}_{3 \mathrm{n}}$ \\
$\ldots$ & $\ldots$ & $\ldots$ & $\ldots$ & $\ldots$ & $\ldots$ \\
$\mathrm{C}$ n & $\mathrm{a}_{\mathrm{n} 1}$ & $\mathrm{a}_{\mathrm{n} 2}$ & $\mathrm{a}_{\mathrm{n} 3}$ & $\ldots$ & $\mathrm{a}_{\mathrm{nn}}$ \\
\hline
\end{tabular}

Each element of the comparison matrix is divided by the sum of its own column sum to generate a normalized matrix (Eq.2).

$$
a_{i j}^{1}=\frac{a_{i j}}{\sum_{i=1}^{n} a_{i j}}
$$

The average of the sum represents the weights of each criterion in pairwise comparison (Eq.3).

$$
w_{i}=\left(\frac{1}{n}\right) \sum_{i=1}^{n} a_{i j}^{\prime}(i, j=1,2,3, \ldots ., n)
$$

The consistency of the pairwise comparison matrix must be calculated to decide the criteria, comparisons are consistent or not. Consistency Index (CI) is one of the methods to define the consistency coefficient of the pairwise comparison matrix (Eq.4).

$$
C I=\frac{\Lambda_{\max }-n}{n-1}
$$

Calculating consistency index depends on the $\lambda \max$ (eigen value) value (Eq.5) and Random Index (RI) value according to the matrix order (Saaty 1994). 


$$
\Lambda_{\max }=\frac{\mathbf{1}}{\mathbf{n}} \sum_{\mathbf{i}=\mathbf{1}}^{\mathbf{n}}\left[\frac{\sum_{\mathbf{j}=\mathbf{1}}^{\mathbf{n}} \mathbf{a}_{\mathbf{i j}} \mathbf{w}_{\mathbf{j}}}{\mathbf{w}_{\mathbf{i}}}\right]
$$

If CR (Eq.6) exceeds 0.1, based on expert knowledge and experience (Saaty and Vargas 1991), recommends a revision of the pairwise comparison matrix with different values.

$$
C R=\frac{C I}{R I}
$$

\subsubsection{Topsis}

In evaluation matrix $A_{i}, \quad A=(1,2, \ldots, n)$ represents the alternatives and $\mathrm{C}_{\mathrm{i}}, \mathrm{C}=(1,2, \ldots, \mathrm{m}) \mathrm{a}$ set of criteria; where $\mathrm{X}_{\mathrm{i}}\left(\mathrm{X}_{11}\right.$ to $\left.\mathrm{X}_{\mathrm{nm}}\right)$ defines the ratings (Eq.7).

\begin{tabular}{llllll}
\hline & $\mathrm{C}_{1}$ & $\mathrm{C}_{2}$ & $\mathrm{C}_{3}$ & $\ldots$ & $\mathrm{C}_{\mathrm{m}}$ \\
\hline $\mathrm{A}_{1}$ & $\mathbf{X}_{11}$ & $\mathbf{X}_{12}$ & $\mathbf{X}_{13}$ & $\ldots$ & $\mathbf{X}_{1 \mathrm{~m}}$ \\
$\mathrm{~A}_{2}$ & $\mathbf{X}_{21}$ & $\mathbf{X}_{22}$ & $\mathbf{X}_{23}$ & $\ldots$ & $\mathbf{X}_{2 \mathrm{~m}}$ \\
$\mathrm{~A}_{3}$ & $\mathbf{X}_{31}$ & $\mathbf{X}_{32}$ & $\mathbf{X}_{33}$ & $\ldots$ & $\mathbf{X}_{3 \mathrm{~m}}$ \\
$\ldots$ & $\ldots$ & $\ldots$ & $\ldots$ & $\ldots$ & $\ldots$ \\
$\mathrm{A}_{\mathrm{n}}$ & $\mathbf{X}_{\mathbf{n} 1}$ & $\mathbf{X}_{\mathbf{n} 2}$ & $\mathbf{X}_{\mathbf{n} 3}$ & $\ldots$ & $\mathbf{X}_{\mathbf{n m}}$ \\
\hline
\end{tabular}

$$
\begin{aligned}
& \mathbf{A}^{+}=\left\{\mathbf{V}_{1}^{+}(\mathbf{x}), \mathbf{V}_{2}^{+}(\mathbf{x}), ., \mathbf{V}_{\mathbf{m}}^{+}(\mathbf{x})\right\}=\left\{\left(\max _{i} v_{i j}(x) \mid j \in j_{1}\right) \min _{i} v_{i j}(x)\left|j \in j_{2}\right| i=1, n\right\} \\
& \mathbf{A}^{-}=\left\{\mathbf{V}_{\mathbf{1}}^{-}(\mathbf{x}), \mathbf{V}_{\mathbf{2}}^{-}(\mathbf{x}), ., \mathbf{V}_{\mathbf{m}}^{-}(\mathbf{x})\right\}=\left\{\left(\min _{i} v_{i j}(x) \mid j \in j_{1}\right) \max _{i} v_{i j}(x)\left|j \in j_{2}\right| i=1, n\right\}
\end{aligned}
$$

$$
\begin{aligned}
& D_{i}^{*}=\sqrt{\sum_{j=1}^{m}\left[V_{i j}(X)-V_{j}^{+}(X)\right]^{2}}, \\
& D_{i}^{-}=\sqrt{\sum_{j=1}^{m}\left[V_{i j}(X)-V_{j}^{-}(X)\right]^{2}}, \quad i=1, \ldots, n
\end{aligned}
$$

Calculate the relative closeness to the ideal solution $\mathrm{Ci}^{*}$ with $\mathrm{Di}^{*}$ and $\mathrm{Di}^{-}$, where $1>\mathrm{Ci}^{*}>0$. The $\mathrm{Ci}^{*}$ values close to 1 will be the better solution relatively (Eq.11).

$$
C_{i}^{*}=\frac{D_{k}^{-}}{D_{k}^{*}+D_{k}^{-}}
$$

\subsubsection{Weight Calculation}

Each criterion is reclassified and mapped via ArcGIS 10.1 software, which are visualized in Figure 2 using Inverse Distance Weighted (IDW) spatial analysis. Criteria maps are illustrated from green to red, which represent suitability from high to low.

The first step of generating suitability maps is weight calculation of physical, chemical, topographical and socio-economic criteria with a pairwise comparison matrix (Table 2). Because chemical parameters and components have vital importance on crop growth, chemical criteria are weighted $60 \%$. Other criteria weights are calculated $20 \%$ for physical and $10 \%$ for topographic and socio-economic criteria because topographic and socio-economic criteria have indirect effect on crop suitability. The weights of the criteria were specified considering recent studies.

Table 2. Crop suitability pairwise matrix

\begin{tabular}{llllll}
\hline $\mathrm{A}_{1}$ & $\mathrm{C}_{1}$ & $\mathrm{C}_{2}$ & $\mathrm{C}_{3}$ & $\mathrm{C}_{4}$ & $\mathrm{~W}$ \\
\hline $\mathrm{C}_{1}$ & 1 & 4.7 & 5 & 5.1 & 0.60036 \\
$\mathrm{C}_{2}$ & $1 / 4.7$ & 1 & 2 & 2.3 & 0.20114 \\
$\mathrm{C}_{3}$ & $1 / 5$ & $1 / 2$ & 1 & 1 & 0.10274 \\
$\mathrm{C}_{4}$ & $1 / 5.1$ & $1 / 2.3$ & $1 / 1$ & 1 & 0.09575 \\
\hline
\end{tabular}

$\mathrm{A}_{1}=$ Crop Suitability, $\mathrm{C}_{1}=$ Chemical, $\mathrm{C}_{2}=$ Physical,

$\mathrm{C}_{3}=$ Topographical, $\mathrm{C}_{4}=$ Socio-Economic, $\mathrm{CR}=0,038, \mathrm{~W}=\mathrm{Weights}$

In the second stage, criteria weights are calculated separately according to the criteria (W1) and main criteria (W2). The CR values of all comparisons are lower than 0.10 indicate that the use of the weights are suitable. W3 weights represent the total weight of each main criterion when generating suitability. All the AHP weights are given in Table 3. 


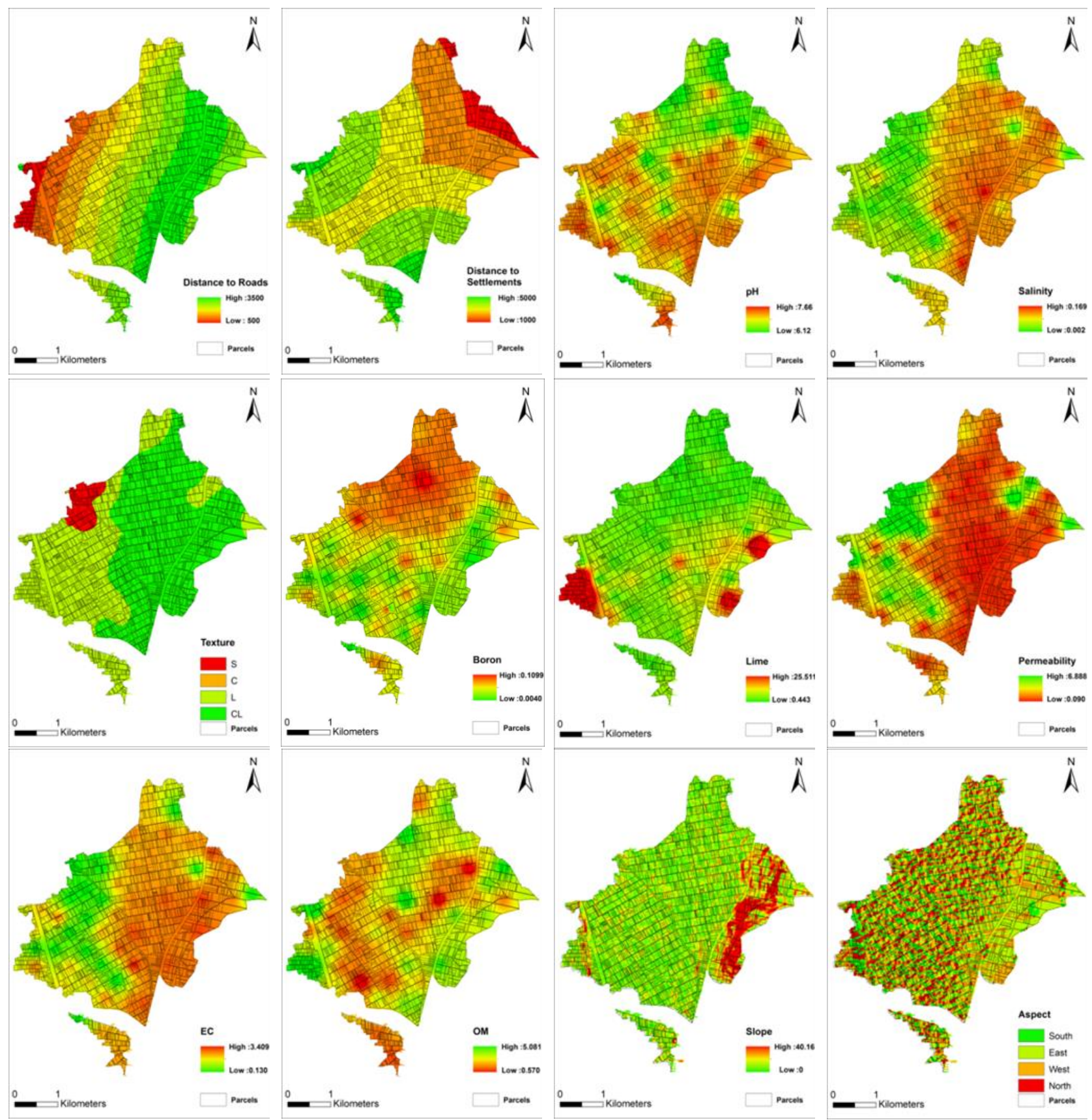

Figure 2. Criteria Maps Distance to roads (DR), Distance to settlements (DS), Ph, Salinity (S), Texture (T), Boron (B), Lime (L), Permeability (P), Electrical Conductivity (EC), Organic Matter (OM), Slope (S), Aspect (A)

Table 3. AHP weights of each criterion

\begin{tabular}{lllll}
\hline Criteria & $\mathrm{W}_{1}$ & Main-Criteria & $\mathrm{W}_{2}$ & $\mathrm{~W}_{3=} \mathrm{W}_{1 \times} \mathrm{W}_{2}$ \\
\hline \multirow{4}{*}{ Chemical } & & $\mathrm{PH}$ & 0.33 & 0.20 \\
& & $\mathrm{EC}$ & 0.12 & 0.07 \\
& \multirow{2}{*}{0,6} & $\mathrm{~B}$ & 0.12 & 0.07 \\
& & $\mathrm{~L}$ & 0.12 & 0.07 \\
\multirow{2}{*}{ Physical } & & $\mathrm{OM}$ & 0.09 & 0.05 \\
& & $\mathrm{~S}$ & 0.19 & 0.11 \\
\hline \multirow{2}{*}{ Topographic } & \multirow{2}{*}{0,2} & $\mathrm{~T}$ & 0.75 & 0.15 \\
& \multirow{2}{*}{ Social-Economic } & $\mathrm{P}$ & 0.25 & 0.05 \\
& \multirow{2}{*}{0,1} & $\mathrm{~S}$ & 0.75 & 0.07 \\
& \multirow{2}{*}{0,1} & $\mathrm{~A}$ & 0.25 & 0.02 \\
\hline
\end{tabular}


After weight calculation with AHP, TOPSIS technique is applied to be able to determine crop suitability. The TOPSIS technique aims to determine the distances from selected alternative to negative and positive ideal solutions. The selected alternative should have the shortest distance from the positive ideal solution and the longest from the negative ideal solution. The respective distances to positive and negative ideal solutions are defined as a similarity index (Hwang and Yoon 1981). In crop suitability analysis, $\mathrm{S} 1$ is considered to be ideal point and the N2 is the negative ideal point for each crop.

The TOPSIS evaluation matrix includes $63 \mathrm{LMU}$ and related rankings in 0-30, 30-60, 60-120 cm depth for 12 criteria which are included in 4 main criteria. The ranking values for each criterion are defined between 1-9 considering the LMU values and crop requirements (Table 1 ). The ranking values are used to calculate $\mathrm{R}$ and $\mathrm{V}$ matrices via $\mathrm{W} 3$ weights that calculated with AHP (Table 2). The positive ideal solution $\mathrm{A}+$ and the negative ideal solution $\mathrm{A}-$, which are the maximum and minimum values of the $\mathrm{V}$ matrix, are calculated.

Based on the $\mathrm{A}+$ and $\mathrm{A}-$ values, distance to positive ideal solutions $\mathrm{Di}^{*}$ and distance to negative ideal solution Di- values are calculated for each LMU. Finally, relative closeness to ideal solution $\mathrm{Ci}^{*}$ values are calculated (Table 4) to determine the land suitability ranking definition. The $\mathrm{Ci}^{*}$ values are classified as follows;

$\mathrm{Ci}^{*}>0.8$ : Highly Suitable (S1),

$0.8>\mathrm{Ci}^{*}>0.65$ : Moderately Suitable (S2),

$0.65>\mathrm{Ci}^{*}>0.50$ : Slightly Suitable (S3),

$0.50>\mathrm{Ci}^{*}>0.40$ : Moderately not Suitable (N1),

$\mathrm{Ci}^{*}<0.40$ : None Suitable (N2).

Table 4. Distances from positive and negative ideal solutions

\begin{tabular}{lllll}
\hline LMU & $\mathrm{Di}^{*}$ & $\mathrm{D}^{-}$ & $\mathrm{Ci}^{*}$ & Classification \\
\hline $1_{(0-30)}$ & 0.007 & 0.033 & 0.82571 & $\mathrm{~S} 2$ \\
$1_{(30-60)}$ & 0.019 & 0.022 & 0.53753 & $\mathrm{~S} 3$ \\
$1_{(60-120)}$ & 0.023 & 0.021 & 0.48719 & $\mathrm{~N} 1$ \\
$2_{(0-30)}$ & 0.013 & 0.031 & 0.70879 & $\mathrm{~S} 2$ \\
$2_{(30-60)}$ & 0.018 & 0.018 & 0.50375 & $\mathrm{~S} 3$ \\
$2_{(60-120)}$ & 0.010 & 0.032 & 0.76626 & $\mathrm{~S} 2$ \\
$\ldots$ & $\ldots$ & $\ldots$ & $\ldots$ & $\ldots$ \\
$63_{(0-30)}$ & 0.008 & 0.030 & 0.79496 & $\mathrm{~S} 2$ \\
$63_{(30-60)}$ & 0.038 & 0.016 & 0.29240 & $\mathrm{~N} 2$ \\
$63_{(60-120)}$ & 0.040 & 0.007 & 0.14884 & $\mathrm{~N} 2$ \\
\hline
\end{tabular}

\section{RESULTS and DISCUSSION}

The suitability index maps are produced according to the $0-30,30-60$ and $60-120 \mathrm{~cm}$ depths of LMU's respectively. The suitability index maps are generated by using $\mathrm{Ci}^{*}$ values which are calculated by TOPSIS method.
Because corn and wheat requirements are quite similar to each other, suitability maps can be investigated together. Wheat and corn are the most widely grown crops in the study area. Addition to this, there are a considerable amount of parcel which has high suitability for wheat and corn. Especially the north of the study area has very high suitability with 0.838 for corn and 0.860 for wheat. The parcels that have very low suitability are quite a few due to the slightly alkaline soils, high salinity and very low permeability values. The lowest suitability index values for corn is 0.14 and for wheat 0.18 . The general suitability of the area is calculated $59 \%$ for corn and $46 \%$ for wheat including S1, S2 and S3.

The clover and sugar beet crop needs high values of boron. However, the boron values of the area are not sufficient for these crops. Addition to this, clover needs moderately alkaline soils, thus, slightly alkaline soils affect the growth respectively. The $\mathrm{S} 1$ is not included in the study area for clover and the $5 \%$ of the study area have very low suitability. The sugar beet suitability index is varied from 0.85 to 0.16 and clover 0.73 to 0.29 . The suitability index maps for clover, wheat, sugar beet and clover are given in Figure 3, 4, 5 and 6.

The suitability ranking (S1, S2, S3, N1 and N2) rates are compared according to the $63 \mathrm{LMU}$ of the study area. The S1, S2 and S3 are assigned as suitable areas and N1, N2 as unsuitable. According to this, 59 $\%$ of the study area have suitability for corn, $43 \%$ for sugar beet, $76 \%$ for clover and $46 \%$ for wheat for 0 $30 \mathrm{~cm}$ depth. The comparisons of the suitability rankings are given in Table 5 and 6.

The suitability ranking rates are compared according to the 2382 parcels. The highest value of the $\mathrm{S} 1$ is 22 for sugar beet. Considering the $\mathrm{S} 1, \mathrm{~S} 2$ and S3 are suitable rankings, 1481 parcels for corn, 1457 parcels for wheat, 2027 parcels for clover and 1127 parcels for sugar beet are suitable. In other words, 1000,22 ha for corn, 985,5 ha for wheat, 1285,71 ha for clover and 764,16 ha of the total 1524,47 ha study area for sugar beet are suitable. The comparisons of the parcel counts are given in Table 6.

Validating suitability maps can only be possible with crop statistics of the study area. Thus, 2016 parcel based crop records are retrieved from Republic Of Turkey Ministry Of Food, Agriculture and Livestock Seydişehir Directorates with using farmer registration system database. As shown in Figure 7, wheat is the most widely grown crop in study area with $80.5 \%$ rate of total crop. However, habits, agricultural incentives and continuously changing prices are more decisive factors than suitability. Due to this, crop records may not reflect agricultural lands suitability. 

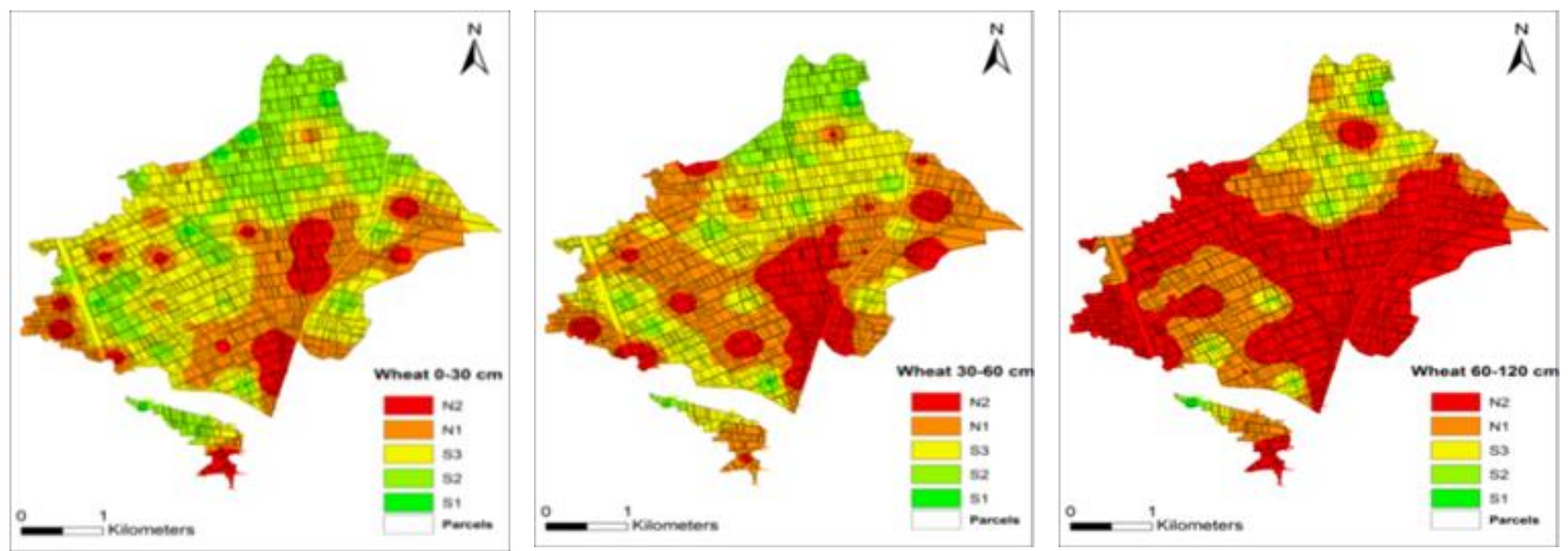

Figure 3. Wheat suitability maps for $0-30 \mathrm{~cm}, 30-60 \mathrm{~cm}$ and $60-120 \mathrm{~cm}$
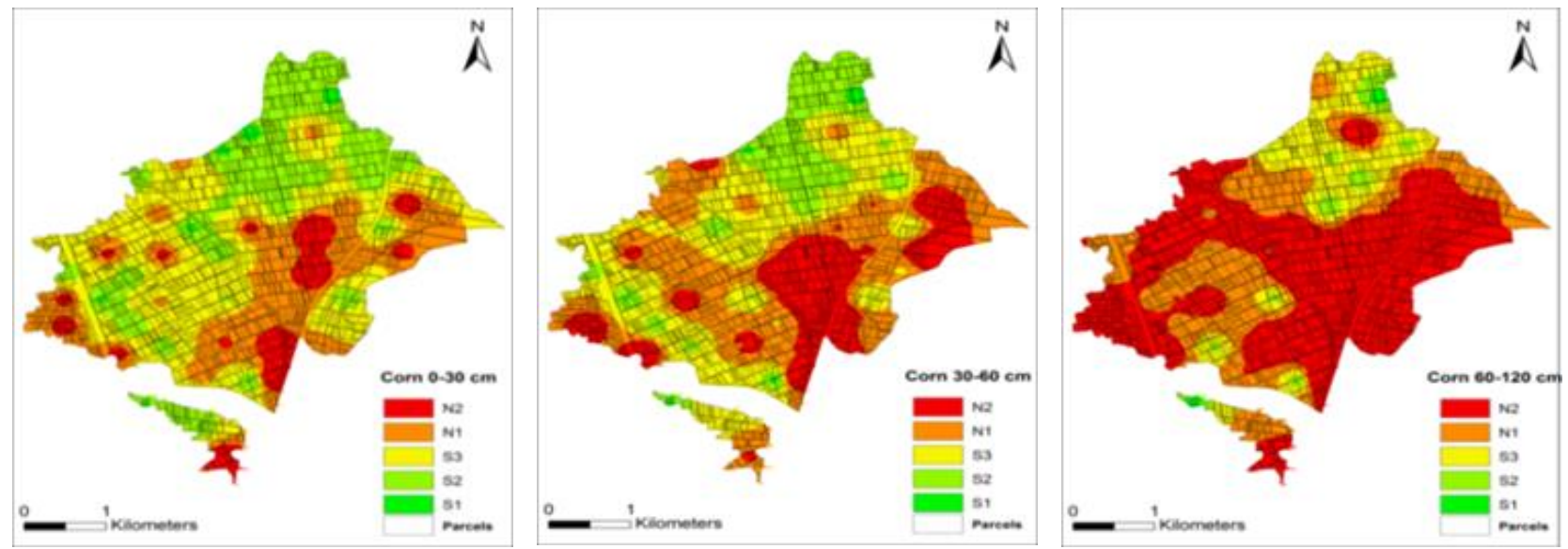

Figure 4. Corn Suitability maps for $0-30 \mathrm{~cm}, 30-60 \mathrm{~cm}$ and $60-120 \mathrm{~cm}$
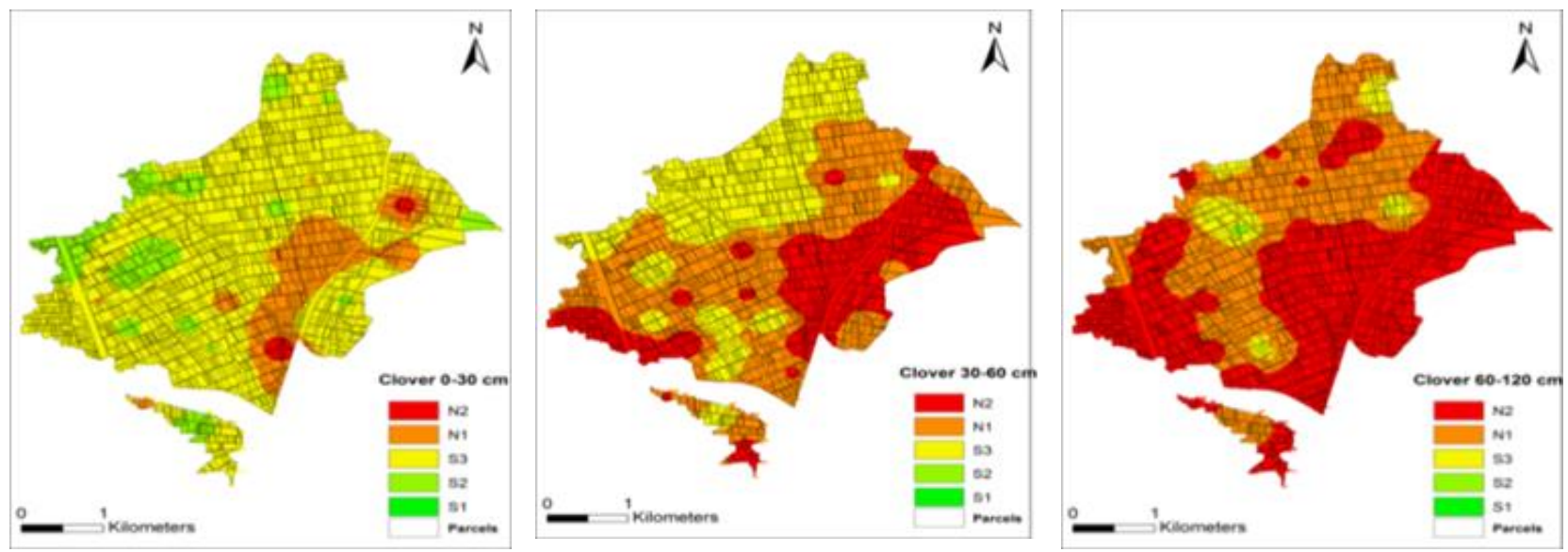

Figure 5. Clover Suitability maps for $0-30 \mathrm{~cm}, 30-60 \mathrm{~cm}$ and $60-120 \mathrm{~cm}$
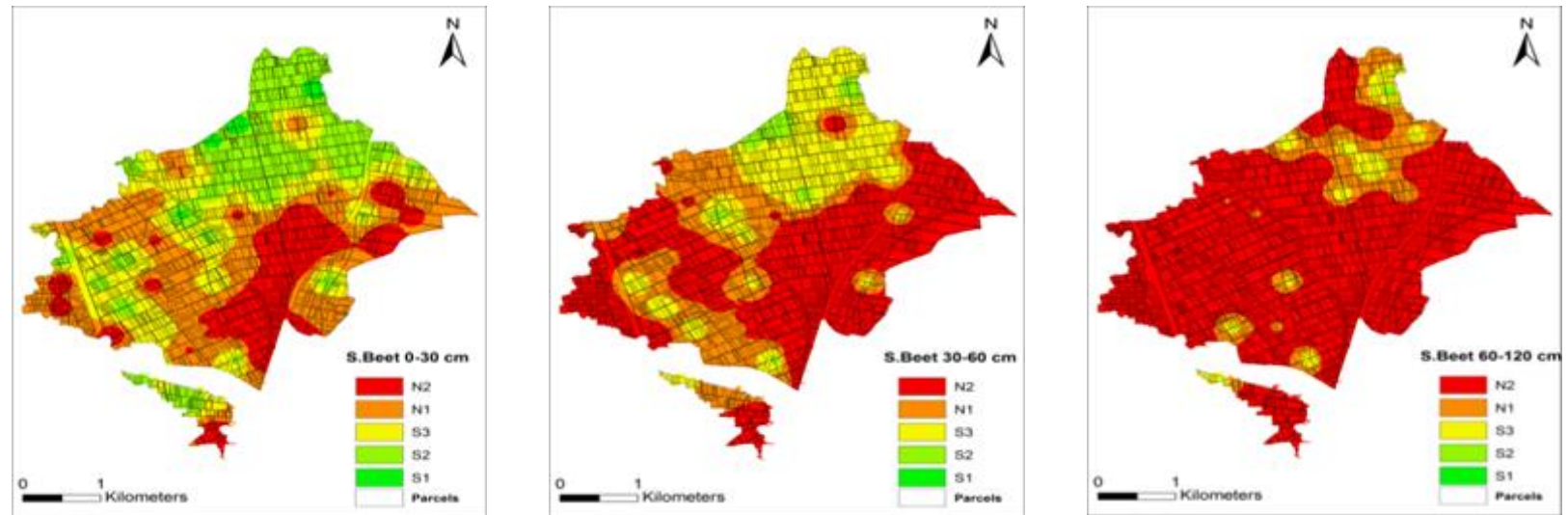

Figure 6. Sugar Beet Suitability maps for $0-30 \mathrm{~cm}, 30-60 \mathrm{~cm}$ and $60-120 \mathrm{~cm}$ 
Table 5. Comparisons of the 63 LMU

\begin{tabular}{|c|c|c|c|c|c|c|c|c|c|c|c|c|}
\hline Class & $\begin{array}{c}\text { Corn } \\
30 \mathrm{~cm}\end{array}$ & $\begin{array}{c}\text { Corn } \\
60 \mathrm{~cm}\end{array}$ & $\begin{array}{c}\text { Corn } \\
120_{\mathrm{cm}}\end{array}$ & $\begin{array}{c}\text { S.Beet } \\
30 \mathrm{~cm}\end{array}$ & $\begin{array}{c}\text { S.Beet } \\
60 \mathrm{~cm}\end{array}$ & $\begin{array}{l}\text { S.Beet } \\
120_{\mathrm{cm}}\end{array}$ & $\begin{array}{c}\text { Clover } \\
30 \mathrm{~cm}\end{array}$ & $\begin{array}{c}\text { Clover } \\
60 \mathrm{~cm}\end{array}$ & $\begin{array}{l}\text { Clover } \\
120_{\mathrm{cm}}\end{array}$ & $\begin{array}{c}\text { Wheat } \\
30 \mathrm{~cm}\end{array}$ & $\begin{array}{c}\text { Wheat } \\
60 \mathrm{~cm}\end{array}$ & $\begin{array}{l}\text { Wheat } \\
120 \mathrm{~cm}\end{array}$ \\
\hline S1 & 7 & 5 & 5 & 4 & 0 & 0 & 0 & 0 & 0 & 6 & 3 & 3 \\
\hline S2 & 30 & 16 & 16 & 21 & 7 & 1 & 15 & 2 & 2 & 9 & 13 & 13 \\
\hline S3 & 0 & 10 & 10 & 2 & 13 & 10 & 33 & 21 & 4 & 14 & 12 & 12 \\
\hline N1 & 12 & 12 & 12 & 12 & 7 & 4 & 12 & 18 & 15 & 15 & 13 & 13 \\
\hline $\mathrm{N} 2$ & 14 & 20 & 20 & 24 & 36 & 48 & 3 & 22 & 42 & 19 & 22 & 22 \\
\hline
\end{tabular}

Table 6. Parcel count comparisons of suitability classes

\begin{tabular}{|c|c|c|c|c|c|c|c|c|c|c|c|c|}
\hline Class & $\begin{array}{l}\text { Corn } \\
30_{\mathrm{cm}}\end{array}$ & $\begin{array}{l}\text { Corn } \\
60 \mathrm{~cm}\end{array}$ & $\begin{array}{l}\text { Corn } \\
120_{\mathrm{cm}}\end{array}$ & $\begin{array}{c}\text { S.Beet } \\
30 \mathrm{~cm}\end{array}$ & $\begin{array}{c}\text { S.Beet } \\
60 \mathrm{~cm}\end{array}$ & $\begin{array}{l}\text { S.Beet } \\
120 \mathrm{~cm}\end{array}$ & $\begin{array}{c}\text { Clover } \\
30 \mathrm{~cm}\end{array}$ & $\begin{array}{c}\text { Clover } \\
60 \mathrm{~cm}\end{array}$ & $\begin{array}{l}\text { Clover } \\
120_{\mathrm{cm}}\end{array}$ & $\begin{array}{c}\text { Wheat } \\
30\end{array}$ & $\begin{array}{c}\text { Wheat } \\
60 \mathrm{~cm}\end{array}$ & $\begin{array}{l}\text { Wheat } \\
120 \mathrm{~cm}\end{array}$ \\
\hline S1 & 19 & 8 & 9 & 21 & 0 & 0 & 0 & 0 & 0 & 22 & 7 & 9 \\
\hline S2 & 585 & 348 & 56 & 533 & 55 & 2 & 270 & 1 & 4 & 580 & 255 & 56 \\
\hline S3 & 877 & 743 & 374 & 573 & 490 & 98 & 1757 & 736 & 124 & 855 & 775 & 367 \\
\hline N1 & 659 & 776 & 619 & 770 & 598 & 295 & 317 & 985 & 874 & 664 & 888 & 545 \\
\hline N2 & 238 & 503 & 1320 & 481 & 1235 & 1983 & 34 & 656 & 1376 & 257 & 453 & 1401 \\
\hline
\end{tabular}

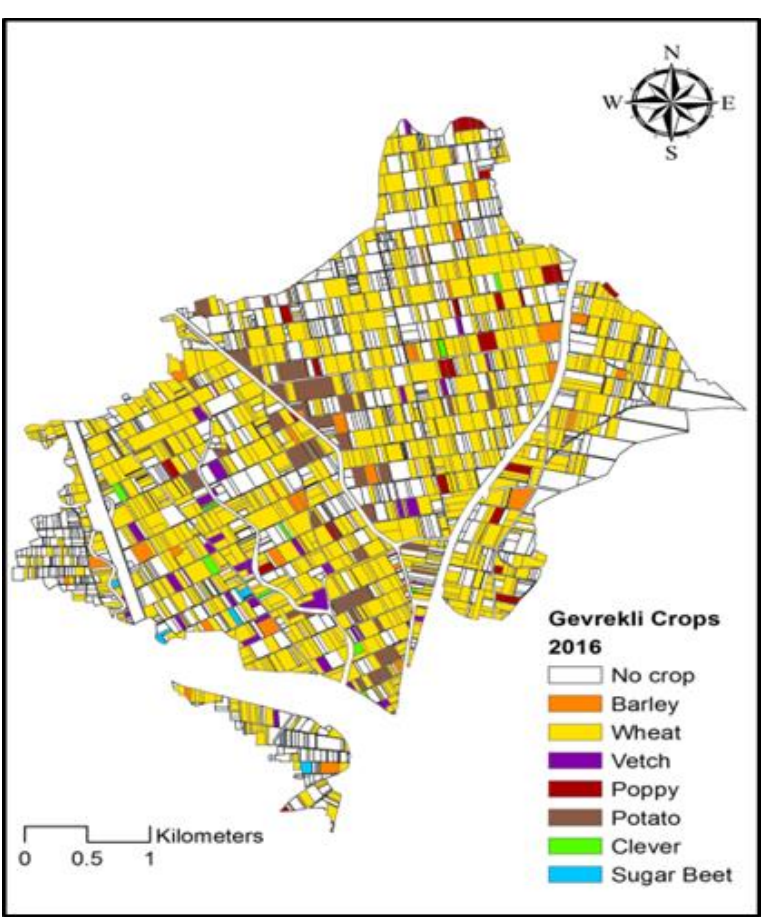

Figure 7. Crop Map of the Gevrekli

\section{CONCLUSION}

Although determining the crop suitability is a very complex study from planning to the establishing stage, the integration of AHP, TOPSIS and GIS functions provide an effective platform to determine the suitability. In this context, the most important factors are the criteria selection and data preparation for the study area. Firstly, the decision makers must decide the priorities of crops. Then, the weights of the criteria can be easily modified with the AHP according to the priorities. Although 12 criteria are used in this study, several criteria can be added such as; meteorological and irrigation. Because the parcels are included in a completed land consolidation project area, all the parcels have an irrigation canal. Meteorological parameters should be observed such as; humidity, soil temperature, wind, wind direction and the minimum and maximum temperature. However, there aren't any distinctive topographical features that meteorological observations can change. Addition to this, these parameters should be included in AHP and TOPSIS. Thus, more realistic crop suitability can be determined by enlarging the scope of the land facilities. Another important issue in this scope is the data collection and accuracy. Because there are 63 LMU in the study area, the accuracy of the suitability decreased relatively. While 63 LMU are enough to decide, higher LMU will be better to determine the suitability accurately.

The comparison of the determined suitable crops and grown crops should be evaluated each year. The suitability results can easily integrate with farmer registration systems or sustainable agricultural management systems. Thus, the consistency of the study and comparisons can be investigated together with irrigation, fertilization and pest control to improve the crop yields.

Although recent studies based on AHP method (Hayashi 2000; Prakash 2003; Sadok et al. 2008; Thapa and Murayama 2008; Chen et al. 2010; Ramírez-García et al. 2015), this study introduced TOPSIS method via AHP weight calculation for crop suitability analysis. Moreover, wheat, corn, clover and sugar beet crops were examined in this study which are the main crop cover of the study area. However, (Roudeillac et al. 1997; Diaby et al. 2010; Ceballos-Silva A \& Lopez-Blanco 2003a; CeballosSilva and Lopez-Blanco, 2003b; Chuong 2007; Li et al. 2011; Chavez et al. 2012; Dinh and Duc 2012; Elaalem 2013; Srdjevic et al. 2014; Cobuloglu and Buyuktahtakın 2015; Kazemi et al. 2016) studied on a special crop type. Thus, this study and method can be applied to a large amount of agricultural lands which crop cover is similar to the study area. This can lead more comprehensive approach for crop management and planning by examining all crops in a study area.

This study also guide to the local authorities as like province agricultural directorates for planning and deciding agricultural incentives. In recent status, directorates are giving incentives to farmers to increase the yield and decrease the expenditures of agricultural activities. However, the suitability of crops are not examining in this stage. Additionally, for rural development, farmers are encouraged for different crop types to provide new economic field. 
Instead of this, determining suitability of all crop types in valuable agricultural lands and deciding crop cover could increase the yield and economic income. Moreover, insufficient irrigation resources can be managed more effectively. For instance, crop types which need less water resources can be decided both considering the suitability and protect the water resources. Nowadays, Konya Karapınar district has been threatened by sinkholes due to the excessive irrigation demand of sugar beet, corn and sunflower crops, which need water mostly.

\section{REFERENCES}

Akar A \& Gökalp E (2018). Designing a sustainable rangeland information system for Turkey. International Journal of Engineering and Geosciences (IJEG), 3(3), 87-97

Arentze T A \& Timmermans H J P (2000) ALBATROSS: A learning-based transportation oriented simulation system. 1-23

Cauwenbergh NV, Biala K, Bielders C, Brouckaert V, et al. (2007). SAFE - a hierarchical framework for assessing the sustainability of agricultural systems. Agriculture, Ecosystems and Environment, 120 (2-4), 229-242

Ceballos-Silva A \& Lopez-Blanco J (2003a). Delineation of suitable areas for crops using a Multi-Criteria Evaluation approach and land use/cover mapping: a case study in Central Mexico. Agricultural Systems 77(2), 117-136. DOI: $10.1016 / S 0308-521 X(02) 00103-8$

Ceballos-Silva A \& López-Blanco J (2003b). Evaluating biophysical variables to identify suitable areas for oat in Central Mexico: a multicriteria and GIS approach. Agriculture, Ecosystems and Environment, 95, 371-377.

Chavez M D, Berentsen P B M \& Lansink O (2012). Assessment of criteria and farming activities for tobacco diversification using the Analytical Hierarchical Process (AHP) technique. Agricultural Systems 111, 53-62. DOI: 10.1016/j.agsy.2012.05.006

Chen Y, Yu J \& Khan S (2010). Spatial sensitivity analysis of multi-criteria weights in GIS-based land suitability evaluation. Environmental Modelling \& Software 25(12), 1582-1591. DOI: 10.1016/j.envsoft.2010.06.001

Chuong H V (2007). Multi-criteria land suitability evaluation for selected fruit crops in Hilly region of central Vietnam. PHD Thesis, Humboldt University, Berlin, Germany.

Cobuloglu H I \& Buyuktahtakın I E (2015). A stochastic multi-criteria decision analysis for sustainable biomass crop selection. Expert Systems with Applications 42(15-16), 60656074. DOI: 10.1016/j.eswa.2015.04.006

Confalonieri R, Francone C, Cappelli G, Stella T et al. (2013). A multi-approach software library for estimating crop suitability to environment. Computers and Electronics in Agriculture 90, 170-175. DOI: 10.1016/j.compag.2012.09.016
Diaby M, Valognes F \& Clement-Demange A (2010). A multicriteria decision approach for selecting hevea clones in Africa. Biotechnology, Agronomy, Society and Environment,14(2), 299-309.

Dinh L C \& Duc T T (2012). Integration of GIS, Group Ahp and Topsis in evaluating sustainable landuse management. International Symposium on Geoinformatics for Spatial Infrastructure Development in Earth and Allied Sciences, Ho Chi Minh, Vietnam.

Elaalem M (2013). A comparison of parametric and fuzzy multi-criteria methods for evaluating land suitability for olive in Jeffara Plain of Libya. APCBEE Procedia 5, 405 - 409. Dubai, UAE

Eliasson A, Jones R J A, Nachtergaele F, Rossiter D G et al. (2010). Common criteria for the redefinition of intermediate less favoured areas in the European Union. Environmental Science \& Policy, 13(8), 766-777.

Elsheikh R, Shariff A R B M, Amiri F, Ahmad N B, Balasundram K S \& Soom M A M (2013). Agriculture land suitability evaluator (ALSE): A decision and planning support tool for tropical and subtropical crops. Computers and Electronics in Agriculture 93, 98-110. DOI: 10.1016/j.compag.2013.02.003

FAO (1976). A framework for land evaluation. Soils Bulletin 32. FAO, Rome. ISBN 925 100111-1.

Ramírez-García J, Carrillo J M, Ruiz M, Alonso-Ayuso M \& Quemada M (2015). Multicriteria decision analysis applied to cover crop species and cultivars selection. Field Crops Research, 175,106-115. DOI: 10.1016/j.fcr.2015.02.008

Hayashi K (2000). Multicriteria analysis for agricultural resource management: a critical survey and future perspectives. European Journal of Operational Research, 122(2), 486500. DOI: 10.1016/S0377-2217(99)00249-0

Hwang C L \& Yoon K (1981). Multiple Attribute Decision Making-Methods and Applications, 186, Springer, Berlin, Heidelberg. ISBN 978-3642-48318-9

Joerin F, Theriault M \& Musy A (2001). Using GIS and outranking multi-criteria analysis for land-use suitability assessment. International Journal of Geographical Information Science, 15 (2), 153174. DOI: $10.1080 / 13658810051030487$

Kazemi H, Sadeghi S \& Akinci H (2016). Developing a land evaluation model for faba bean cultivation using geographic information system and multicriteria analysis (A case study: Gonbad-Kavous region, Iran). Ecological Indicators, 63, 37-47. DOI: $10.1016 /$ j.ecolind.2015.11.021

Li Y Y, Wang X R \& Huang C L (2011). Key street tree species selection in urban areas. African Journal of Agricultural Research, 6(15), 3539-3550. DOI: $10.5897 /$ AJAR11.461

Peters M L \& Zelewski S (2007). TOPSIS as a technology for efficiency analysis. Zeitschrift für Ausbildung und Hochschulkontakt, 36(1), 1-9. (In Deutsch). 
Prakash T N (2003). Land Suitability Analysis for Agricultural Crops: A Fuzzy Multicriteria Decision Making Approach. MS Thesis, International Institute for Geo-information Science and Earth Observation. Netherlands.

Radulescu C Z, Radulescu M, Rahoveanu A T, Rahoveanu MT \& Beciu S (2011). A multicriteria approach for assessment of agricultural systems in context of sustainable agriculture. Recent Researches in Applied Informatics, 167171.

Radulescu C Z, Rahoveanu A T \& Radulescu M (2010). A hybrid multi-criteria method for performance evaluation of romanian South Muntenia Region in context of sustainable agriculture. Proceedings of the International Conference on Applied Computer Science (ACS), 1, 303-308.

Rigby D, Woodhouse P, Young T \& Burton M (2001). Constructing a farm level indicator of sustainable practice. Ecological Economics 39(3), 463-478.

Roudeillac P, Faedi W \& Lavialle O (1997). A multicriteria decision aid to determine the genetic performance of strawberry through a varietal observatory network in Western Europe. Acta Horticulturae, 439, 307-317.

Saaty T L (1977). A scaling method for priorities in hierarchical structures. Journal of Mathematical Psychology, 15(3), 234-281.

Saaty T L (1994). Fundamentals of decision making and priority theory with the analytical hierarchy process. RWS Publucations, Pittsburg, 69-84. ISBN: 9780962031762

Saaty T L (2001) Decision Making with Dependence and Feedback: The Analytic Network Process, 2nd edition, PRWS Publications, Pittsburgh PA. ISBN: 9780962031793

Saaty T L \& Vargas L G (1991). Prediction, Projection and Forecasting. Springer Netherlands. ISBN 978-94-015-7954-4

Sadok W, Angevin F, Bergez J, Bockstaller C et al. (2008). Ex ante assessment of the sustainability of alternative cropping systems: implications for using multi-criteria decision-aid methods. A review. Agronamy and Sustainable
Development, 28, 163-174. DOI: 10.1051/agro:2007043

Sarı F, Ceylan D A, Özcan M M \& Özcan M M (2020). A comparison of multicriteria decision analysis techniques for determining beekeeping suitability. Apidologie. DOI: 10.1007/s13592020-00736-7.

Srdjevic B, Srdjevic Z, Kolarov V (2004). Group evaluation of walnut cultivars as a multi criterion decision-making process. CIGR International Conference, Beijing, China.

Wang F, Hall G B, Subaryono (1990). Fuzzy information representation and processing in conventional GIS software: data base design and application. International Journal of Geographical Information System, 4(3), 261283. DOI: $10.1080 / 02693799008941546$

Thapa R B, Murayama Y (2008). Land evaluation for peri-urban agriculture using analytical hierarchical process and geographic information system techniques: A case study of Hanoi. Land use policy, 25(2), 225-239. DOI: 10.1016/j.landusepol.2007.06.004

Triantaphyllou E (2000). Multi-criteria decision making methods: A comparative study, 44, Springer, Boston, MA. ISBN: 978-1-47573157-6

Yu J, Chen Y, Wu J, Khan S (2011). Cellular automatabased spatial multi-criteria land suitability simulation for irrigated agriculture. International Journal of Geographical Information Science, 25 (1), 131-148.

Zeleny M (1982). Multiple Criteria Decision-making. McGraw-Hill, New York, NY, 563 pages. ISBN: 9780070727953

URL 1. Turkish Statistical Institute Official web site. https://biruni.tuik.gov.tr/medas/?kn=92\&local $\mathrm{e}=\operatorname{tr}$ (Accessed date: 18.05.2020)

URL 2. FAO Official web site. Available at "http://www.fao.org/3/x5648e/x5648e0j.htm (Accessed date: 18.05.2020).

Zolekar R B \& Bhagat V S (2015). Multi-criteria land suitability analysis for agriculture in hilly zone: Remote sensing and GIS approach. Computers and Electronics in Agriculture, 118, 300-321. 